DOI:

10.1515/manment-2015-0008

ANDRZEJ CZYŻEWSKI

JAKUB STANISZEWSKI

\title{
Contemporary agrarian question and alternative ways to its solution'
}

Professor Andrzej Czyżewski Poznan University of Economics Head of the Department of Macro and Agricultural Economics

Jakub Staniszewski Poznan University of Economics Ph.D. student in the Department of Macro and Agricultural Economics

\section{Introduction}

With declining share of the agriculture in the most developed countries GDPs, question about the further development of this sector gradually disappear from mainstream economics. As the most of the neoliberal growth models assume land factor to be constant, the agrarian question is considered as solved, by the implementation of the industrial model of agricultural development. However, we must be aware, that such a simplistic approach, in the long term turns out to be inadequate to reality. Turning farms into factories, which, through the use of certain inputs (fertilizers, pesticides, feeds, seeds etc.) produce certain outputs (cereals, meat, milk, etc.), and which principal rule is to maximize effects and minimize costs, leads to harmful results. Agriculture in fact, more than any other sector of the economy, operates in touch with three basic dimensions of economic activity.

1 This paper uses the excerpts of the prof. A. Czyżewski's speech entitled: "Teoriopoznawcze przesłanki rozwoju rolnictwa rodzinnego", presented on the conference "Ekonomiczne i prawne mechanizmy wspierania i ochrony rolnictwa rodzinnego $\mathrm{w}$ Polsce i innych państwach Unii Europejskiej", which was held on 23-24 October 2014 at Warsaw University of Life Sciences - SGGW 
This feature, in the case when the two of them - the social and environmental - are not included in the economic calculations, implies serious consequences. In the field of environment, we should consider problems such as loss of biodiversity, pollution and soil erosion and excessive consumption of water resources. In the social sphere, loss of vitality of rural areas and the cases of various diseases associated with industrial food production methods, are the most severe consequences to be mentioned. Moreover, even in the economic domain, which in the case of industrial agriculture plays a crucial role, model reveals its theoretical shortcomings.

In the most developed countries, the possibility of further industrialization of agriculture exhausts, when this process inevitably encounter a barrier, arising due to the low price and income elasticity of food products demand (Czyżewski, Henisz-Matuszczak 2005, p. 63). Even when the use of crops for biofuel production may contribute to overcoming of this barrier (Zegar 2007, p. 5), this alternative use of food products still remains highly controversial (Krasowicz 2009). Considering problems of the agriculture sector we also cannot omit the peculiar paradox of development, which appears when some economies have problems with the food surplus, while the number of the least developed countries still haven't solved the problem of food security for its citizens. It is estimated, that in the global scale malnourished is still 805 million people, or $11.3 \%$ of the world population. (FAO, IFAD \& WFP 2014). So it turns out that, as so far, none of the used agricultural models, have led to a final solution of the agrarian question, but only partially mitigated its negative consequences (Czyżewski, Matuszczak 2011). Facing these problems, the present form of the world agricultural sector, as well as its theoretical foundations, in the form of industrial agricultural model, require a deep revision. Future of the agriculture depends on the implementation of the new paradigm, corresponding to needs of sustainable agricultural production. That means taking into account not only the cost of purely economic factors, but also these with a social and ecological nature (Zegar 2005). Agriculture in fact, with its multi-dimensional structure, is a highly specific sector, requiring institutional support. Furthermore, proper targeting of the aid makes it possible to stimulate rural economy on many levels, with relatively little financial effort.

According to these facts, authors in the first place, are going to show the paradigm of sustainable development of agriculture and rural areas, as a counterbalance to the industrial model. Next, confront the assumptions of the both concepts with the contemporary agrarian question. And finally, present the basic assumptions of the common agricultural policy (CAP) for 2013-2020, 
as a practical evidence of a gradual change in the paradigm of agricultural development in the European Union.

\section{Contemporary agrarian question}

Multidimensionality of the agriculture sector problems are reflected in the complexity of the agrarian question. Known also under the name of the agriculture or the peasant question, this problem, in the economic sphere, refers to the food security provision. In the social sphere to farmers deprivation, and in the political sphere to the disappearance of the peasants, as a distinct social group (Zegar 2010, p. 780). Czyżewski \& Matuszczak (2011, p. 5) see the essence of the problem in the land, as the production factor which, in circumstances of the consumption compulsion, is non-competitive to the other two - labor and capital. As a result of this contradiction farmers, to meet the food needs of others, are "fated to permanent income disparity, mainly due to the lack of mobility of land factor." Also Wilkin (2009, p. 11), as the main components of the agrarian question indicates - incompliance of the agriculture with competitive market economy, lower agricultural productivity and lower farm income levels. McMichael (2006, p. 481) place emphasis on the specific objection of rural communities in relation to the neo-liberal paradigm of capital accumulation. From this point of view, one of the main challenges is finding the path of the agriculture development, which will base on other than capital-intensive model. The broadest definition of the agrarian question indicates its deterministic nature of agriculture relevance in the economy and the related dilemmas (Wilkin 1986). According to this holistic approach, we could present the entire spectrum of the agrarian question dilemmas. This study, however, will focus only on the selected issues, connected with industrial and sustainable models of agriculture development. In this context, it is worth to take a closer look at the problem of concentration and specialization in agriculture. In these processes, as well as in the adequate to the natural conditions technological progress, some researchers find agriculture competitiveness sources (Michna, Mierosławska, Chmielewska et al. 2005, p. 7). However, there are still a number of countries with fragmented agrarian structures, which determines lower productivity of labor and land resources in the agriculture (Kołodziejczak 2008). This problem also applies to Polish agriculture, which is still characterized by structural inefficiency (Poczta 2012, p. 98). Lower efficiency means lower income, and in the longer term, limited capacity of accumulation in agriculture. In addition, agricultural 
production depends highly on biological processes and natural-climatic conditions which are mostly beyond the control of the farmers (Rembisz, Sielska, Bezat 2011, p. 9) and make their incomes even more uncertain. Parallel to these processes, in the surrounding of agriculture, especially in the markets of agricultural inputs, concentration processes from year to year are gaining strength, even worsening the farmer's market position (Czyżewski 2013, p. 833). So in the case of agriculture and its environment we can speak about concentration asymmetry, acting on the disadvantage of agriculture. Żmija (2011), quoting works of Galbraith, recognizes concentration processes in the situation of economic growth as natural. However, for the sake of the further development, formation of "counterweight" to the appearing monopolies is essential. In the case of the agricultural sector such functions may perform producers organizations. Unfortunately, in many countries, including Poland, strength of these groups is too small to successfully defend the interests of farmers and sustain their position in the chain of food production. Moreover, conflicts occur not only between agriculture and its economic environment, but also between countries, because in the ongoing process of liberalization and globalization of agri-food trade there are winning and losing countries. Adamowicz (2008, p. 56) indicates that in theory, this process should favor the most underdeveloped countries (with cheap labor and favorable natural conditions), at the cost of the industrialized countries. However, they cannot afford to abandon agricultural production due to its strategic nature and public, and environmental function that this sector fulfill. A step further in his reflections goes Stiglitz (2006) stating that small farms from poor countries lose from globalization to concentrated and specialized farms, strongly linked with the processing industry. Also Stigliz (1987) associates agrarian question with traditional market failures. He recognizes the particular problems of: (1) the incompleteness of the market for agricultural insurance, (2) the existence of public goods in agriculture (although in his concept they are limited only to the irrigation system), (3) imperfect information, which is available to agricultural producers, (4) the presence of externalities (again, he limits them to a positive phenomenon of diffusion of technology). Moreover, author identifies income disparity as a market failure. In this context, it is worth to mention Thurow's (1971) point of view, where he recognizes the relative alignment of income as a specific type of public good. In fact, the study of economic rents account, carried out on data from the input-output model for the Polish economy for the years 1995, 2000 and 2005 (Czyżewski B., Mrówczyńska-Kamińska 2011), provides empirical evidence of the inefficiency of the market allocation 
mechanism. Within the flows between agriculture and the rest of the economy occurs drainage of economic surplus from agriculture to its environment. Kapusta (2005, p. 190) specifies two main ways to solve the problem of income disparity. The first one is the transfer of labor out of agriculture, what can be identified with the paradigm of agriculture industrialization. The second one is creating non-agricultural sources of income for peasants, what can be associated with the rural areas multifunctional model - one of the basic elements of the sustainable agriculture paradigm. Moreover, author notes that both of these models coexist in contemporary practice of agricultural policy, what indicates the duality of the current path of agriculture development (Matuszczak 2007, p. 102). In this article, we will try to prove that in recent years a model of sustainable agriculture development begins to spread and to limit the expansion of the industrial model.

\section{Two paths of agriculture development and expected abandonment of one of them}

Antonymic perception of the two agricultural development concepts is not a new issue. Negative effects of agriculture intensification has already been seen in the late 80s and 90s. Curtis \& Dunlap (1990, p. 598-599) distinguished two paradigms of agriculture - conventional, which can be identified with industrial agriculture and alternative, with the characteristic of sustainable agriculture. They also signaled the key elements of competing models. Centralized, specialized, dependent, competing, dominating and exploiting nature, conventional agriculture was placed in opposition to decentralized, diversified, independent, communal, harmonized and restrained alternative model.

Crucial on the way to finding compromise between these opposite "quantity and quality" paradigms is measuring the value of public goods. Although many methods have been developed to estimate these values, especially by the experimental economics (Maciejczak 2009), none of them proved to be so versatile and reliable, that on its basis public goods could be internalized in economic calculations. However, even in a situation where the economic calculus omit the element of public goods, industrial agricultural paradigm turns out to be ineffective in the long run. In principle, the industrial model should contribute to: 1) the outflow of labor resources, used inefficiently in agriculture, to other sectors of the economy, where their performance will be higher, and where they contribute better to the overall economic growth; 2) productivity and income growth in the agricultural sector (by reducing the people to which the income 
is shared); 3) increase in mechanization, use of chemicals and specialization of agriculture (Zegar 2009, p. 259). However, application of this model requires a considerable amount of budget and social costs. The process is described by Czyżewski \& Henisz-Matuszczak (2005). In the first phase of implementation, significant expenditure target current and retraining costs of land and labor resources released from agriculture, thanks to increase in productivity. Next, it is necessary to use pricing instruments to compensate for the ongoing increase in intermediate consumption. These actions, implies the need for intervention to defend the national, non-competitive production, against cheaper imported goods. In the long term, costs of this policy (through differences in the domestic and international food prices) are shifted from taxpayers to consumers. At the same time, industrial paradigm encourages to increase production, what in the face of inelastic demand for food, results in surpluses, which allocation costs charge state. Furthermore, according to the law of diminishing marginal returns, in each successive production cycle, increase in intensification, concentration and mechanization of cultivation, must bear a smaller increase in effect. This law is perfectly illustrated by the decline in efficiency of nitrogen fertilizers in agriculture. While in the $60 \mathrm{~s}$ with $1 \mathrm{~kg}$ of fertilizer was possible to achieve yields of approx. $75 \mathrm{~kg}$ of cereals, in 1995, it was only $25 \mathrm{~kg}$ (Tilman, Cassman, Matson et al., 2002, p. 678). So the performance of industrial model is limited from both supply and demand side, what ultimately determines its failure in maintaining income parity. It turns out that even without taking into account, not valued by the market, costs and effects of the public goods provision by agriculture, industrial development model in the long term is going to fail. Their inclusion in the scope of the assessment can only worsen the results of analysis. And so, in the environmental dimension, one of the main arguments against industrial model is its negative impact on biodiversity. With specialization, agriculture production is concentrated on one specific plant, what leads to highest efficiency, through the mechanization and intensive usage of chemicals. However, this has dire consequences for fields biodiversity. According to studies conducted in six European countries, there is a statistically significant correlation between the intensity of agricultural production (represented by the scale of the use of nitrogen fertilizers) and richness of plant biodiversity on surveyed fields, that diminishes in exponential rate (Kleijn et al. 2009). Opponents of the industrial model also indicate soil erosion, caused by intensive agriculture. Empirical evidence are provided by studies of Montgomery (2009). They show that the erosion rate of soils used under intensive agriculture is comparable to analogous rate of the soils in the Alpine regions. Significant is the fact that the use of special methods 
of conservation tillage can reduce the rate nineteen fold. Finally, we cannot forget about the over-consumption of water resources, which become more and more scarce. Predictions show that by 2025 renewable water resources per capita will fall from $6600 \mathrm{~m}^{3}$ to $4800 \mathrm{~m}^{3}$ (Cosgrove \& Rijsberman 2014, p. 21). What is important, farmland irrigation was one of the basic assumptions of the "green revolution" and significantly contributed to the increase in yields. However, in many cases water used for irrigation comes from underground sources (this process is also called over-pumping) traditionally used for non-agricultural purposes. Therefore, further productivity increase through irrigation will lead to higher competition for water resources (Matson et al. 1997). In the social dimension, loss in vitality of rural areas is the most common argument against industrial agriculture. In this context, Zegar (2012, p. 133) states: „peculiarity of the overall development impact to the rural areas lies in the fact that as so far changes were made through agriculture, and more specifically the family farms, which dominated and determined the vitality of villages". In this situations where family farms are being replaced with industrial monocultures, villages depopulate and lose its natural character, traditions and culture. Eventually, various diseases associated with produced in industrial way food cannot be ignored. Among the most serious concerns, emerging in the face of more and more often cases of so-called diseases of affluence and its diet background, following issues can be distinguished: 1) pollution from farms detrimental to local residents; 2) more frequent intoxication with pathogens from food, such as Salmonella, Listeria or BSE; 3) animal growth stimulated with antibiotics, which cause the appearance of increasingly resistant bacteria; 4 ) the issue of genetically modified organisms (Horrigan, Lawrence, Walker 2002).

The response to the depletion of economic opportunities in the industrial paradigm, and its negative impact on the social and environmental dimension is sustainable agriculture development model. The concept is not new, and its history is well described by Paszkowski (2001, p. 47-48). He ascribes key role in the evolution of the concept to the Brundtland Declaration (1987) and later The Earth Summit, held in June 1992 in Rio de Janeiro, where has been articulated demand for implementing Sustainable Agriculture and Rural Development (SARD). But how sustainable agriculture should be defined? Woś (1992) points the ambiguity of this concept in the literature and through its revision, specifies common features of the definitions, such as: 1) use of natural resources in a way that enables their self-renewal; 2) increase in agricultural production achieved only by increasing productivity of resources, not by their consumption; 3) low susceptibility to fluctuations and shocks; 4) symbiosis of 
agricultural and eco-regional purposes. An interesting voice into discussion brings Slangen (2001), who distinguishes between two types of sustainability weak and strong. The first one, which is derived from the economics, as the goal of sustainability takes prosperity maximization. The availability of resources for the next generation is not unconditional, but depends on human creativity. This should provide technologies for resource the protection, before they start to disappear on rate, faster than allowing them to reproduce. Strong sustainability implies an absolute primacy of ecology and environment preservation. Among agricultural economists more popular seems to be weak approach, assuming a balance between economic, environmental and social dimensions of agriculture. Moreover, in order to emphasize the importance of the social component the term socially sustainable agriculture is used. This concept assumes (Woś, Zegar 2004, p. 16): 1) recognition of agriculture as a provider of not only market, but also public goods; 2) associating microeconomic and social sense of efficiency; 3 ) combining novelty with tradition; 4 ) harmonizing the interests of various actors of the development process, including the "dumb" ones; 5) progress used for widening consumers and producers choice range; 6) advantages coming with globalization and integration process available for all. Even broader concept, connected with sustainability, is multifunctionality in agriculture. Repeating after Adamowicz (2004, p. 13) we can distinguish the following functions of agriculture: 1) production - production of food and non-food products; 2) environmental and spatial - proper use of the environment, the quality of the landscape, contamination prevention, protection of biodiversity; 3) service - maintaining the productivity of land resources, abundance of natural and social environment, employment of existing labor resources, proper waste management, sustainability of agriculture. Regardless of the theory and models adapted to it, their implementation requires regulatory and financing activities of the state. Objectives and instruments of this activity constantly evolve. The best example of it are changes in the practice of the EU's Common Agricultural Policy.

\section{Reorientation in EU Common Agricultural Policy}

In the economic theory, sustainable agriculture model seems to be the only alternative to the industrial model and the next stage of the evolution of Common Agriculture Policy (CAP). But to what extent this concept is reflected in the political practice? At the global level, signs of changing perceptions of agricultural intervention can be found in the OECD documents (2006, p. 56). 
They indicate as a key factor of change in agriculture policy optic, concentration of financial support not so much on the sector, but addressed locations, not on the subsidies, but investments. However, OECD as an organization, has a limited impact on agricultural policies of its members.

Situation is different in the case of the European Union, which moved agricultural policies of its members to the supranational level. And the evolution of the CAP instruments is the strongest sign of transition from the paradigm of agriculture industrialization to its sustainability. The evolution of the CAP is described, in a synthetic, way in the OECD report (2011, p. 65). Although the CAP adapts to the market situation in many ways, in the context of this article we will focus on those that directly affect the sustainability of agriculture. Financial perspective 2013-2020 will be discussed separately, as a kind of novelty in this field. Present shape of the CAP is the result of many years of transformations, which have been accelerated after the MacSharry's reform, which took place in 1992. Then, for the first time appear postulate of decoupling - shift from production subsidizing, to direct farms support. In this way, level of farms financing became partially decoupled from production efficiency and ceased to be preferential for farms with high production efficiency. In this system of support, the amount of aid is determined by agricultural area, and transfers are the direct support of agricultural income. Furthermore, one of the requirements of support has become partial (10-15\%) land resting. While the main purpose of this construction was to reduce food overproduction, at the same time also environmental objective was pursued. With identical reasons, implementation of environmental programs and subsidies for afforestation of least fertile land was initiated.

Further changes in the instruments of the CAP, toward its sustainability, took place at the turn of the centuries with the document so-called Agenda 2000. A new idea here was introduction of the Pillar II payments, which were allocated to support rural development. Thus, in the scope of the CAP has been implemented another element of sustainability - the social issue. This trend was reflected even stronger by increase in payments for less favored areas. Further changes on brought Luxembourg reform (2003), which significantly changed the shape of EU subsidies. First of all, system of direct payments was standardized by introducing Single Payment Scheme, (SPS), what besides the obvious benefits in the form of simplification, allowed (in theory) fully decouple the amount of aid from crop yields. In practice, separation cannot be considered as more than apparent, because the initial amount of support per hectare was established based on historical payments, dependent on the previous performance. 
Moreover, division made in 2003, in only slightly modified form survived until today, vaguely petrifying structures of subsidies and maintaining preferences for countries with the highest productivity. So as long as payments are not really flattened and criteria for their distribution deeply reformed, we cannot speak about total separation from performance. Among the CAP instruments we can also find from 2003 cross-compliance requirements, the fulfillment of which is a prerequisite for obtaining subsidies. This tool in a completely direct way has impact on the greening of agricultural production methods. Finally, as an element, on the one hand, rationalizing distribution support, and on the other hand, demotivating for further concentration of production, modulation was introduced. Modulation assumes a gradual reduction of support for the largest beneficiaries. Moreover, the funds obtained in this way are transferred to the second pillar, entirely intended to purposes related to the paradigm of sustainable agriculture development.

More changes in the CAP instruments took place in 2008 on the occasion of the midterm review (Health Check), which confirmed the way to the sustainability of CAP and deepened initiated in previous years changes. And so we come to the present day, beginning a new financial framework. Negotiations of the CAP post 2013 were very turbulent, mostly due to conflicts of interests and discrepancies between Member States (Czyżewski \& Stępień 2012). The fact that, the new solutions will come into force from the beginning of 2015 - with the year delay, reliably proves it. However, the negotiations eventually resulted in the new shape of $\mathrm{CAP}$, which, as perhaps never in history, is consistent with the postulates of the sustainable agricultural production. To the greatest extend, changes in the new financial perspective applied to direct payments and we will focus on them here. First of all, it is mandatory in all EU Member States, that $30 \%$ of the national payment envelope will be earmarked for farms that meet additional requirements for the "greening" of agricultural production - diversification of crops, maintenance of existing permanent grassland and farmland ecological area. What's important, in a similar proportion expenditures financed from the second pillar has been associated with ecological goals. For the sake of the social sustainability of rural areas, to prevent "aging" in rural societies, Member States were given the possibility to allocate up to $2 \%$ of the national envelope for additional support to young farmers. For greater efficiency of direct payments distribution, simplified scheme for small farms was implemented. In order to support the economically weakest farms, a possibility of redistribution up to $30 \%$ of the national payment envelope to their needs was created. The introduction of the Basic Payment Scheme (BPS) 
across the European Union and revision of differences in the payment per ha between countries (by 2020 the $1 / 3$ of the difference between the current level of subsidies, and $90 \%$ of the average payments in the EU will be eliminated), are also a step towards a unified direct payment system, ultimately decoupled from agricultural production efficiency. Finally, particularly important due to the preservation of the vitality of rural areas is the definition of the active farmer. The purpose of this definition is to limit flows of direct payments to people who purchased the land for non agricultural purposes. This tool should also prevent from speculative transactions on agriculture land and from direct payments extortion. Land previously acquired for these purposes now may return to the farmers. The evolution of the CAP initiated at the beginning of the $90 \mathrm{~s}$ is a great example of the transition from the industrial model of agriculture, to the sustainable one. We can predict that these processes, which occurred in the EU in the first place, due to the relative scarcity of agricultural resources, in the next few years will find wider application in other countries, employing industrial model of agricultural development.

\section{Conclusions}

Although the share of agriculture in GDP of the most developed countries in the world has been steadily decreasing, consumption compulsion and the sector's strategic role in the country's spatial policy, force financial intervention in this area. In addition, a number of countries, located on the opposite pole of the development, is still facing the problem of malnutrition. Between these two groups situate countries like Poland, where agriculture structural inefficiency determines the need for intervention. Therefore, regardless of economy's stage of development, states are still in the face of unsolved agrarian question, which premises are: lack of mobility of land factor, concentration asymmetry in agribusiness sector, globalization and drainage of economic surplus from agriculture through price scissors mechanism, etc. Previous agriculture policy implemented to cope with the negative effects of these issues was based on the paradigm of industrial agriculture development. This model assumes adaptation of microeconomic efficiency and productivity criteria in a case of farms, just as in the case of industrial plants. However, in the long run, this approach faces a demand barrier, manifested by the growing production surpluses in the face of limited consumption needs, which causes a decrease in prices and further worsening of the farmers economic situation. Also, omitting the costs of externalities coming with agricultural production, 
leads to excessive environmental degradation in rural areas and social deprivation of villages. Symptoms of these processes are loss of biodiversity, pollution and soil erosion, excessive consumption of water resources, loss of rural areas vitality and the occurrence of various diseases associated with food produced in a industrial way. Existence of these shortcomings of industrial agriculture development model is a prerequisite to change it to a sustainable model - assuming more harmonious development of all three spheres of rural economy - economic, social and environmental. This concept originates from ecological movements of the 70's and 80's ultimately was formed in the early 90s. Since then it is gradually introduced into the European Union interventionist practices, redefining the objectives and instruments of the Common Agricultural Policy. In the fullest way, agricultural sustainability postulate is manifested in changes that occurred in the structure of the CAP for the period 2014-2020, where for the first time, a specific part of the aid will be given to the farmers for providing specific public goods. This structure of the CAP, may be a "milestone" in the path towards establishing universal environmental tax, which funds will be used to pay farmers for providing environmental non-market goods.

\section{Summary}

\section{Contemporary agrarian question and alternative ways to its solution}

Article presents a complex problem of an agrarian question - its causes, consequences and ways of mitigating the negative effects associated with it. Featured, competing models of agricultural development - industrial and sustainable, are characterized. Also the negative effects of excessive industrialization of agricultural production, leading to the failure of this model, are shown. At the same time, as an alternative, authors indicate sustainable agricultural model, engaging in its account economic, social and environmental costs. As an example of the transition from the industrial model to sustainable development model, the EU common agricultural policy has been described, including its future form in the financial perspective 2014-2020.

Key words: sustainable agriculture development model, industrial agriculture development model, agrarian question, common agriculture policy development, CAP 2014-2020. 


\section{Streszczenie}

\section{Współczesna kwestia agrarna i alternatywne metody jej rozwiązania}

Artykuł przybliża złożony problem występowania kwestii agrarnej - jej przyczyny, konsekwencje oraz sposoby niwelowania negatywnych zjawisk z nią związanych. Wyróżnione, konkurencyjne modele rozwoju rolnictwa - industrialny i zrównoważony, zostają przybliżone i scharakteryzowane. Ponadto, ukazane zostają negatywne efekty nadmiernej industrializacji produkcji rolnej, prowadzące do zawodności tego modelu. Jednocześnie, jako alternatywa dla jego stosowania wskazany zostaje model rolnictwa zrównoważonego, ujmujący w swym rachunku kosztów elementy ekonomiczne, społeczne i środowiskowe. Jako przykład przechodzenia z modelu industrialnego do zrównoważonego opisana zostaje dotychczasowa ewolucja wspólnej polityki rolnej, a także jej najbliższa przyszłość w perspektywie finansowej 2014-2020.

\section{Słowa}

kluczowe: model zrównoważonego rozwoju rolnictwa, model rolnictwa industrialnego, kwestia agrarna, ewolucja wspólnej polityki rolnej, WPR 2014-2020.

\section{References}

1. Adamowicz M. (2008), Teoretyczne uwarunkowania rozwoju rolnictwa z uwzględnieniem procesów globalizacji i międzynarodowej integracji , "Roczniki Nauk Rolniczych", seria G, No. 94(2).

2. Adamowicz M. (2004), Wielofunkcyjność rolnictwa jako podstawa przewartościowań w polityce rolnej, "Wieś i Rolnictwo", No. 4.

3. Baum R. (2008), Zrównoważony rozwój rolnictwa i kryteria jego oceny, "Journal Agribusiness and Rural Development", No. 1 (7).

4. Beus C. E., Dunlap R. E. (1990), Conventional versus Alternative Agriculture: The Paradigmatic Roots of the Debate, "Rural sociology", No. 55 (4).

5. Brundtland G.H. (1987), Report of the World Commission on environment and development: "our common future.", United Nations, New York.

6. Cosgrove W. J., Rijsberman, F. R. (2014), World water vision: making water everybody's business, World Water Council, Oxon-New York.

7. Czyżewski A. (2013), O nowy paradygmat rozwoju rolnictwa, „Ekonomista”, No. 6.

8. Czyżewski A., Henisz-Matuszczak A. (2005), Makroekonomiczne uwarunkowania rolnictwa industrialnego i społecznie zrównoważonego. Refleksje na temat sprzężeń regulacyjnych i realnych, in:. Zegar J. S (ed.), Koncepcja badań nad rolnictwem społecznie zrównoważonym, IERiGŻ, Warszawa. 
9. Czyżewski A., Matuszczak A. (2011), Dylematy kwestii agrarnej w panoramie dziejów, Zeszyty Naukowe SGGW, Ekonomika i Organizacja Gospodarki Żywnościowej, No. 90.

10. Czyżewski A., Stępień S. (2012), Dostosowania mechanizmów wspólnej polityki rolnej do oczekiwań państw członkowskich, „Ekonomista”, No. 2.

11. Czyżewski B., Mrówczyńska-Kamińska A. (2011), Przeptywy międzygałęziowe $i$ podziat rent $w$ sektorze rolno-żywnościowym $w$ Polsce $w$ latach 1995-2005, „Ekonomista”, No. 2.

12. FAO, IFAD, WFP (2014), The State of Food Insecurity in the World 2014. Strengthening the enabling environment for food security and nutrition, FAO, Rome.

13. Horrigan L., Lawrence R. S., Walker P. (2002), How sustainable agriculture can address the environmental and human health harms of industrial agriculture, "Environmental health perspectives", No. 110 (5).

14. Kapusta F. (2005), Niektóre problemy kwestii rolnej w Polsce na poczatku XXI wieku, in: Adamowicz, M. (ed.), Kwestia agrarna w Polsce i na świecie, Wydawnictwo SGGW, Warsaw.

15. Kleijn D., i in. (2009), On the relationship between farmland biodiversity and land-use intensity in Europe, "Proceedings of the royal society B: biological sciences", No. 276.

16. Kołodziejczak M. (2008), Efektywność wykorzystania zasobów pracy i ziemi $w$ rolnictwie Unii Europejskiej, „Roczniki Naukowe Stowarzyszenia Ekonomistów Rolnictwa i Agrobiznesu", No. 10 (1).

17. KrasowiczS. (2008), Wptyw produkcji roślin energetycznych na rynek żywności, "Studia raporty IUNG-PIB", Zeszyt 11.

18. Maciejczak M. (2009), Rolnictwo i obszary wiejskie źródtem dóbr publicznychprzegląd literatury, „Ekonomika i Organizacja Gospodarki Żywnościowej”, Zeszyty Naukowe SGGW, No. 4(75).

19. Matson P. A., Parton W. J., Power A. G., Swift M. J. (1997), Agricultural intensification and ecosystem properties. "Science", No. 277(5325).

20. Matuszczak A. (2007), Dualny rozwój rolnictwa i obszarów wiejskich, in: Czyżewski A. (ed.) Uniwersalia polityki rolnej w gospodarce rynkowej ujęcie makro i mikroekonomiczne, AE, Poznan.

21. McMichael P., (2006), Reframing development: global peasant movements and the new agrarian question, "Canadian Journal of Development Studies/ Revue canadienne d'études du développement", No. 27(4).

22. Michna W., Mierosławska A., Chmielewska B., Lidke D., (2005), Zróżnicowanie funkcji gospodarstw rolnych w ujęciu przestrzennym, Instytut Ekonomiki Rolnictwa i Gospodarki Żywnościowej - Państwowy Instytut Badawczy, Warszawa.

23. Montgomery D. R. (2007), Soil erosion and agricultural sustainability, "Proceedings of the National Academy of Sciences", No. 104(33).

24. OECD, (2006), The New Rural Paradigm: Policies and Governance, OECD Publications, Paris. 
25. OECD, (2011), Evaluation of Agricultural Policy Reforms in the European Union, OECD Publishing, Paris.

26. Paszkowski, S., 2001, Ewolucja idei rolnictwa zrównoważonego i rozwoju terenów wiejskich (SARD), Wieś i Rolnictwo, No. 1, s. 45-63.

27. Poczta, W., 2012, Przemiany w rolnictwie ze szczególnym uwzględnieniem przemian strukturalnych, in: Wilkin, J., Nurzyńska, I. (ed.), Polska wieś 2012. Raport o stanie wsi., Wydawnictwo naukowe SCHOLAR, Warsaw.

28. Rembisz, W., Sielska, A., Bezat, A., 2011, Popytowo uwarunkowany model wzrostu produkcji rolno-żywnościowej, Instytut Ekonomiki Rolnictwa i Gospodarki Żywnościowej Państwowy Instytut Badawczy, Warsaw.

29. Slangen L. H. (2001), Sustainable agriculture: getting the institutions right, CEESA discussion paper/Humboldt-Universität Berlin, No. 1, Department of Agricultural Economics and Social Sciences, Berlin.

30. Stiglitz J. E. (1987), Some theoretical aspects of agricultural policies, The World Bank Research Observer, No. 2(1).

31. Stiglitz J. E. (2006), Globalizacja, Wyd. Naukowe PWN, Warsaw.

32. Thurow L. C. (1971), The income distribution as a pure public good, "The Quarterly Journal of Economics", No. 85 (2).

33. Tilman D., Cassman K. G., Matson P. A., Naylor R., Polasky S. (2002), Agricultural sustainability and intensive production practices, "Nature", No. 418 (6898).

34. Wilkin J. (1986), Wspótczesna kwestia agrarna, Państwowe Wydawnictwo Naukowe, Warszawa.

35. WilkinJ.(2009),Wielofunkcyjnośćrolnictwa-konceptualizacjaioperacjonalizacja zjawiska, „Wieś i Rolnictwo”, No. 4 (145).

36. Woś A. (1992), Rolnictwo zrównoważone, Zagadnienia Ekonomiki Rolnej, No. 1-3.

37. Woś A., Zegar J. S. (2004), Rolnictwo społecznie zrównoważone-w poszukiwaniu nowego modelu dla Polski, „Wieś i Rolnictwo”, No. 3.

38. Zegar J. S. (2005), Koncepcja badań nad rolnictwem społecznie zrównoważonym. in:Zegar,J.,S.(ed.), Koncepcjabadańnad rolnictwem społeczniezrównoważonym. Instytut Ekonomiki Rolnictwa i Gospodarki Żywnościowej Państwowy Instytut Badawczy, Warsaw.

39. Zegar J. S. (2007), Przestanki nowej ekonomiki rolnictwa, "Zagadnienia Ekonomiki Rolnej", No. 4.

40. Zegar J. S. (2009), Kwestia koncentracji ziemi w polskim rolnictwie indywidualnym, „Roczniki Nauk Rolniczych. Seria G”, No. 96 (4).

41. Zegar J. S. (2010), Ekonomia wobec kwestii agrarnej, „Ekonomista”, No. 6.

42. Zegar J. S. (2013), Rola drobnych gospodarstw rolnych w procesie społecznie zrównoważonego rozwoju obszarów wiejskich, „Problemy Drobnych Gospodarstw Rolnych", No. 1.

43. Żmija D. (2011), Dylematy dotyczące aktywnej roli państwa wobszarze rolnictwa, "Zeszyty Naukowe Uniwersytetu Ekonomicznego w Krakowie”, No. 863. 